being seientific primarily, they have degenerated into social and mutual admiration societies.

By denying a person admission into the county society, one is denied admission into the state and national association. This state of affairs could hardly have been intended when the laws of these organizations were first instituted. I suspect the very respectable minority of the profession, if not a major. ity, would welcome some plan by which this condition could be altered, and by so doing have many energetic and capable medical men inside of these organizations, and thereby help to relieve the demoralized state into which the profession has fallen in many sections of the country.

It should not be possible for a county society to cast an unalterable stigma on a member of the profession, while at the same time he has no means of defending himself. Our general law convicts no one without a fair trial by jury, and the appli cant for membership in a county society should have the same privilege.

I have no ax to grind in bringing this subject forward, as I am a member in good standing in both my county and state societies, and am eligible to membership in the American Medical Association. One the contrary, I believe I am acting for the good of the whole profession in making an effort to have our societies placed on a solid and equitable foundation.

I have been steadily engaged in practice for over thirty-one years and have always taken an interest in medical society work. In the natural course of events, I will, in a few years, step down and out, and if $I$ can in a small way help to start a movement that will be of benefit to the profession in general, 1 will feel amply repaid.

The remedy I would suggest-the national association at its meeting soon to take place, could profitably take up this subject, and by discussion secure a general opinion-is for the American Medical Associatron to require each state and county society to be chartered, then provide that an applicant shall have the right of appeal to the state and national societies in case of rejection. There is no doubt but there are many among the ablest in the profession, who are outside of medical organizations, and who claim that they have been de. prived of a right, and without their side being allowed a hearing.

H. G. MaUZeY, M.I).

\section{Antiseptic Treatment of Smallpox.}

Houston, Texas, May 21, 1901.

To the Editor:-THE JourNaL of May 11 contains a communication from Dr. A. Bryan, Detroit, Mich., in which he claims to be "the original author of what may aptly be termed the antiseptic treatment of the disease (smallpox)." The date of the publication of this theory and practice in regard to smallpox is given as 1895 . This theory and practice may have been original with Dr. Bryan, but in March, 1894, this same treatment and theory was thoroughly presented in the Texas Sanitarian, as originating with Dr. 1. C. Osborne, of Cleburne, Texas. Dr. Osborne, however, was not the first physician to publish this theory. In August, 1896, I had the pleasure of receiving from Dr. J. Kornitzer, of Socorro, N. M., a pamphlet published by him in February, 1880, at Cincinnati, Ohio, in which he set forth the same views as Dr. Osborne, and that were, later, set forth by Dr. Bryan.

The Texas Sanitarian is now the Texas Medical News, so if Dr. Bryan cares to look into the subject further he can obtain the desired information from the aforementioned journal of Austin, Texas. Very truly, S. C. RED, M.D. [Several other communications have also been received relative to this matter, the others giving personal experience with no references.-...SD.]

\section{A Suggestion to Preparatory Schoois Regarding Morality from the Common-sense Standpoint.}

\section{New Haven, Conn., May 23, 1901}

To the Fditor:-The prevention of venereal diseases is an important subject. Legalized prostitution has its advantages and disadvantages, but the teaching our young men the results of common venereal disorders, has never been attempted in the curriculum of our preparatory schools. If an obli- gatory course of lectures on the common complications of gonorrhea, whancroid, and syphilis were to be given in our large schools where young men are prepared for the universities, it seems as if it might have much weight.

The lecturus should be given by a physician of experience and should cover the common dangers incident to the disorders, viz.: etiology, symptoms, complications, and sequels. If these lectures were delivered to the graduating class of the preparatory schools, it might have a good effect on the future actions of its members.

The lectures should not be intended to intimidate men, but simply to present morality from its common-sense standpoint, if nothing more.

To-day men are more enlightened than ever. Why not break down the so-called false modesty and educate our young fellows in the real dangers, as well as enlargement of their muscles. Men at college are influenced easily as a rule, if matters are set clearly before them, and if they knew beforehand, in most cases they would not make these mistakes.

\section{G. Totten-MoMaster, M.D.}

\section{Anesthetization During Sleep.}

Nashur.le Tenv., May 20, 1901

' $T$ 'o the Editor:-If the anesthetization of children during sleep is of medicolegal interest I can add one case to the three reported hy Dr. Paugh in Trre Journal of May 18. A boy of 18 or 20 months was brought to the elinic of Dr. J. A. Bodine, of the New York Polyclinic for circumcision. The child was found to be asleep in the mother's arms and the gradual administration of chloroform was begun without disturbing its slumbers. Complete surgical anesthesia was finally produced without any sign of irritation or symptom of awakening. Recovcry from anesthesia was rapid, the ehild being in much better humor for having been spared the fright and shock of fored anesthesia. The procedure is uncommon, but by no means impossible or even difficult of achievement.

$$
\text { W. C. Welburn, M.D. }
$$

\section{Memphis in 1902.}

The Memphis Medical Society has, after thoroughly convassing the situation through proper committees, unanimously roted to invite the Americin Mrdical Association to meet in Memphis. Tenn., at its regular annual meeting in 1902 . The Cotton Exchange, Business Men's Club, Passenger Association and all commercial interests in the city are anxious to have Memphis selected as the next meeting-place. Memphis, while her hotel capacity is not as large as it night be, compares favorably with any other city of her size. The hotel capacity is approximately 1500 , without crowding, and there are definite promises to care for 1560 comfortably, 2200 by crowding, and 3225 by auxiliary resources, namely respectable boardinghouses. The auxiłiary resources will cover only rooms in easy reach of the hotels and cafes. Aside from the hotels Memphis offers her homes. Meeting-places for the different Sections, and banquet halls, etc. have been fully planned for

W. Britt Burns.

\section{Saratoga Springs in 1902}

In selecting a place for the next meeting of the Associstion, an eflort should be made to find a place than can accommodate all possible delegates, friends and business people inferested, and that too without crowding or making it necessary to engage accommodations two or three months in advance. Among, the places that will cxtend an invitation to the Associariox for its next annual meeting will be Saratoga Springs, N. Y. In extending this invitation Saratoga Springs can and will guarantee, practically unlimited, thoroughly first-class accommodatirns at prices which will suit every purse. Its sunmer hotels are the largest in the world, and any or all of them will be open to the accommodation of the Association. Two of its largest hotels will accommodate about three thousand guest;, two others about two thousand, and four or five smaller ones irom three hundred to five hundred each, and all of these, in cluding the convention hall, within a distance of exch other of four city blocks, and this estimate is based on the actual num. 